\title{
Consumption behavior and the lack of financial literacy among teens
}

\author{
Sifa Asri Trisnani ${ }^{1}$, Atika Dian Adriyai ${ }^{2}$, Rifky Aulia Wandansari ${ }^{3}$, \\ Wikan Isthika ${ }^{4}$ \\ 1,2,3,4 Universitas Dian Nuswantoro, Semarang, Indonesia
}

\begin{abstract}
Purpose - The main purpose of this study is to examine role of financial literacy, peer conformity, and hedonic lifestyle towards teenagers' consumption behavior.
\end{abstract}

Method - Consumer behavior explains the desire to have excessive consumption. The population in this study were all adolescents high school and university in the region of Central Semarang, amounting to 26583 students, with a sample of 100 adolescents. This study uses a quantitative approach to data collection methods in the form of a questionnaire. The analytical method used is multiple linear regression analysis.

Result - Peer conformity, hedonistic lifestyle, and financial literacy simultaneously influence consumer behavior adolescent high school and university in the Middle Semarang with a contribution of $37 \%$. Partially significance value 0769 for peer conformity and 0. 992 for financial literacy while lifestyle 0:00 hedonic significance value. In this study, only hedonic factors that influence consumer behavior of teenagers.

Implication - This study can be used to understand behavior in teenager, especially in terms of purchase and consumption behavior.

Originaility- This research examine financial literacy in teenager phase.

Keywords: consumer; conformity; hedonist; financial literacy

\footnotetext{
${ }^{1}$ Author correspondence: Sifa Asri Trisnani, sifaasritrisnani@gmail.com, Universitas Negeri Semarang, Sekaran, Kec. Gn. Pati, Kota Semarang, Jawa Tengah 50229, Indonesia
} 


\section{Introduction}

Currently, shopping activities are no longer used to meet the needs of a person, but the fact of shopping has experienced the actual shift function.

JIEMB | 192 Consumption could be interpreted as an activity to fulfill the lifestyle, which can indicate social status in the community environment. When a need is fulfilled, there will be another need arose, ownership of an item. This, of course, will cause problems from the economy side of a person. Someone could concern about fulfilling their desires rather than fulfill their needs. When they fulfill unnecessary needs, it can be said that they have a consumptive behavior (Sembiring, in Nurachma, 2017).

The teenager is one of a contributor who dominates the consumption. Adolescence is a period in which they demonstrate their existence. Based on observations, it can be said if adolescents spend more of their money on personal needs such as going to the mall, watching entertainment, eating at restaurants, and others than it means to buy school needs or even set aside their money to save.

They do it not with their income, but from the allowance they receive from parents. Some even ask parents more because there are other desires that have not yet been reached. All this is done to follow the prestige in their environment.

Adolescents tend to have unstable nature. This state will cause uncertain emotions about something. Seen from the direct observation of researchers, that adolescents who cannot fulfill their desires will be hit by a sense of disappointment, anxiety, and anger that can harm themselves and those around them.

By the issues raised above, the purpose of this study was to determine the effect of parental income, conformity, hedonist style, and understanding of financial literacy of the adolescent consumer behavior in Semarang. 


\section{Literature review}

\section{Consumptive behavior}

Actions or activities of the man himself who has a very broad sense, among others: walk, talk, cry, laugh, work, study, write, or read. From the description, it can be concluded that human behavior is all activities or human activity, whether observed directly or which can not be observed by outsiders (Notoatmodjo, 2003). Dahlan (Al-Hifghifari 2003, H.144) stated that consumer behavior is a behavior that is characterized by luxurious and extravagant life, the use of all the things that are considered the most expensive and provide satisfaction and physical comfort as much as possible as well as their patterns of human life that is controlled and is driven by a desire to meet the desires, the sheer enjoyment.

\section{Peer conformity}

Conformity is a type of social influence when someone changes their attitudes and behavior to match existing social norms. Peer conformity affects teenagers to behave consumptive. Myers (in prime 2017), conformity in a group causes the pressure behavior of the group to require that person to do something outside of their desires as to equate fashion lifestyle so that later can avoid censure and isolation of a group play. Results of research Perdana (2017) demonstrated an association between peer conformity with consumer behavior in the student of the Faculty of Psychology, the University of Diponegoro, in 2016.

H1: Conformity influences consumer behavior

\section{Hedonic lifestyle}

The lifestyle adopted by most teenagers hedonic reflects your lifestyle. The hedonistic lifestyle was a negative impact of globalization and modern sass. Hedonism is a philosophy of joy life just from the material alone as the main purpose of life. Saxon will do anything to satisfy unlimited desires. They will 
buy anything you think they can reflect the level of their social status, not seen how important it is useful or not goods.

Measures of social status/lifestyle luxury are the main motive of the JIEMB | 194 consumer society of consumption activity. By displaying branded goods, famous, and expensive or more luxury appearance is a common symptom hedonism where they have a high sense of pride in the ownership.

Life in the city center also took part in this activity. It can be seen from the number of shopping centers which spread out, selling imported goods, branded and well known, of course at a price high enough to make the financial thinning. In practice, the more likely hedonistic lifestyle practiced by teenagers. Because, again, in adolescence, a person is in a period of transition for identity.

At the time of the search for identity, the hedonistic lifestyle offers fun for teens. So it makes it a teenager to continue to maintain or continue the lifestyle. Hedonists, not in spite of their poor financial literacy. Someone who knows about financial literacy will maximize the use of their financial well-in in other words, would not use the money for just a prestige group.

H2: Hedonic Lifestyle effect on consumer behavior

\section{Financial literacy}

Financial literacy is closely connected with financial managing. The better a person can manage their finance, the higher the level of their financial literacy. Financial literacy is a knowledge to plan and manage your finances well that continues to be lived both consciously and unconsciously. Financial literacy should be a basic need for someone to manage their finances Ulfatun (Julian, Ananda, \& Andriani, 2018).

Financial literacy can be started by the family. In this environment, financial literacy is determined by the parents' role in providing financial education (Widyati, 2012). But it is possible if a new financial literacy is taught as a teenager because adolescence is a period where people are interested in learning something new. 


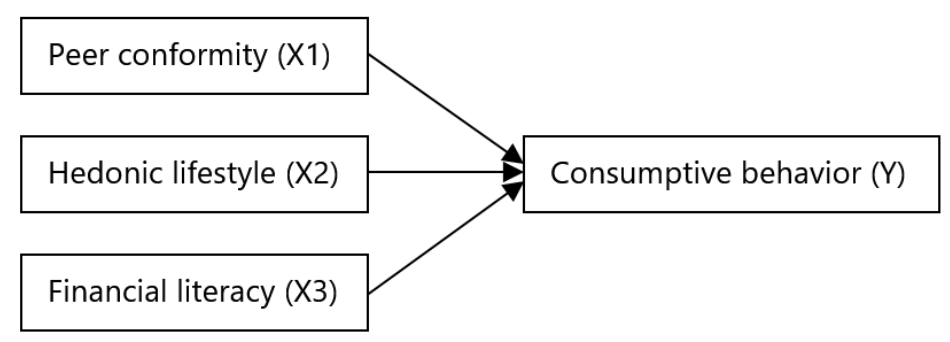

Figure. 1 Research framework

The adolescent age range of 15-22 years who are still largely formal education both at school and university above. Teenagers in high school have passed the junior formula education, which is at present given junior financial literacy materials such as economics, income, consumption, and usability money.

Supposedly teenage junior high school can apply material after admission to pursue high grama, which is SMA. Moreover, high school teenagers who majored in social studies course materials were obtained financial literacy is greater than the material obtained in junior high.

Likewise, students at this level are usually adolescents who have the freedom to manage financial decisions. Students should be able to independently manage their finances properly and be able to account for all the decisions that have been taken.

H3: Financial literacy influence on consumer behavior

\section{Research methods}

This research data using this type of primary data in the form of a questionnaire. The primary data of the questionnaire distributed to the entire sample that teens at the high school level and the University of Central Semarang. The sampling technique used is accidental. This technique allows anyone who met randomly at school, in the shopping center, or anywhere with 
researchers on the condition that the person meets the necessary criteria, and each has a chance to be selected. The method used in the selection of the sample is the solving method, which can be calculated using the formula:

$$
n=\frac{N}{1+N e^{2}}
$$

Information :

$\mathrm{n}$ : Number of Samples

$\mathrm{N}$ : Number of Total Population

E: Tolerance Error

This type of research is a quantitative study using multiple linear regression analysis. The research was done in high school and university in Semarang Tengah. Determination of the population in Semarang Central based on data from the founding of the mall that was issued by the Central Bureau of Statistics where there are five (5) Mall in the city, and 3 (three) of them were in the area of Semarang Central, it is suspected may cause consumerism in adolescents around, the increasing number of malls that exist, the more likely they can remove saturation premises being consumptive, this opinion is in line with the Urban Social observers UGM, Hastangka stating "mall growth fueled a rise of consumerism desire" (DNH, 2016).

The data used as the sample is taken using a questionnaire distributed directly to the respondents. The population used in this study can be seen from the number of all high school students and students at the University of Central Semarang as many as 26583. The population used in this study can be specified in Table 1.

Of the population is unknown, researchers can determine the number of samples with the boundary condition for the maximum error is 0.10 or $10 \%$. The calculation is as follows:

$$
n=\frac{26583}{1+26583 \times 0.10^{2}}=99.62
$$


Table 1. Total population

\begin{tabular}{ll}
\hline Name of school/university & Total students \\
\hline SMA Negeri 03 & 1306 \\
SMA Negeri 05 & 1188 \\
SMAS Kebon Dalem & 147 \\
SMAS Kolese Loyola & 797 \\
SMAS Mataram & 0 \\
SMAS Nusaputera & 103 \\
SMAS Theresiana 1 & 238 \\
SMAS Walisongo & 160 \\
Universitas Dian Nuswantoro & 14924 \\
Universitas AKI & 616 \\
Universitas 17 Agustus 1945 & 7104 \\
\hline Total & 26583 \\
\hline
\end{tabular}

Based on the calculations above, show results in 99.62 or equivalent to 100. Of the total sample of the entire population as many as 100 surrounding the high school students and students of the University of Central Semarang. The criteria for the respondents, aged 15-22 years, which is within the range of a person is still considered a teenager.

Data analysis techniques used in this study is the use of a set of data that is taken, then do the analyst continued that quantitative analysis technique such as test instruments wherein the test is no test of validity and reliability test, after test instrument then continued with the classical assumption, among others test normality, heteroscedasticity test and test multicollinearity and data processing using multiple linear regression method with SPSS 23.

$$
\begin{array}{ll}
Y=a+b_{1} X_{1}+b_{2} X_{2}+b_{3} X_{3}+e \\
Y & : \text { Consumptive behavior } \\
a & : \text { Constants } \\
b_{1} b_{2} b_{3} & : \text { Regression coefficients } \\
X_{1} & : \text { Conformity peers } \\
X_{2} & : \text { Hedonic lifestyle } \\
X 3 & : \text { Financial literacy } \\
\mathrm{e} & : \text { Error term }
\end{array}
$$




\section{Results and discussion}

Table 2 shows the amount of data used was 100 respondents consisted of five variables. Variable Income Parents with one indicator has the lowest value

JIEMB | 198 (minimum) 1, and the highest score (Maximum) is 5, while the average value (Mean) at 3:04 with a standard deviation of 0:13 which is much smaller than the mean value, which means the value of the mean a good representation of the overall data.

Variable conformity with the number 5 questions has the lowest value (minimum) 7, and the highest (Maximum) is 25 , while the average value (Mean) of 16.93 with a standard deviation of 0.32 which is much smaller than the mean value, which means that the mean value is a good representation of the overall data. Variable hedonistic lifestyle with five the questions has the lowest value (minimum) 7, and the highest (Maximum) is 23, while the average value (Mean) of 13.68 with a standard deviation of 0.35 which is much smaller than the mean value, which means the value means a good representation of the overall data.

Variable financial literacy with several questions 11 has the lowest value (minimum) 27, and the highest (Maximum) is 55 , while the average value (Mean) of 43.86 with a standard deviation of 0.61 which is much smaller than the mean value, which means the value of the mean a good representation

Table 2. Result of descriptive statistic

\begin{tabular}{|c|c|c|c|c|c|c|}
\hline & & $\begin{array}{l}\text { Parent's } \\
\text { income }\end{array}$ & Conformity & $\begin{array}{l}\text { Hedonic } \\
\text { lifestyle }\end{array}$ & $\begin{array}{l}\text { Financial } \\
\text { literacy }\end{array}$ & $\begin{array}{c}\text { Consumptive } \\
\text { behavior }\end{array}$ \\
\hline \multirow{2}{*}{ N } & valid & 100 & 100 & 100 & 100 & 100 \\
\hline & missing & 0 & 0 & 0 & 0 & 0 \\
\hline \multicolumn{2}{|c|}{ Mean } & 3.0400 & 16.9300 & 13.6800 & 43.8600 & 31.6600 \\
\hline \multicolumn{2}{|c|}{ Std. error of mean } & .13627 & .32232 & .35187 & .61775 & .48434 \\
\hline \multicolumn{2}{|c|}{ Std. deviation } & 1.36271 & 3.22320 & 3.51872 & 6.17754 & 4.84345 \\
\hline \multicolumn{2}{|c|}{ Variance } & 1,857 & 10389 & 12381 & 38162 & 23459 \\
\hline \multicolumn{2}{|c|}{ Range } & 4.00 & $18: 00$ & $16: 00$ & 28.00 & 26.00 \\
\hline \multicolumn{2}{|c|}{ Minimum } & 1:00 & 7:00 & 7:00 & 27.00 & $20: 00$ \\
\hline \multicolumn{2}{|c|}{ Maximum } & 5:00 & 25.00 & 23:00 & 55.00 & 46.00 \\
\hline
\end{tabular}


of the overall data. Variable consumer behavior with ten questions has the lowest value (minimum) 20, and the highest (Maximum) is 46, while the average value (Mean) of 31.66 with a standard deviation of 0:48 which is much smaller than the mean value, which means that the mean value is a good representation of the overall data.

Data used primary data obtained through questionnaires, while the source of the data from responses to questionnaires was distributed to 100 high school students and students. The questionnaire consisted of 32 statements divided into five parts consisting of one of the parent's income statement, the statement of conformity 5, 5 statement about the hedonistic lifestyle, 11 statements about financial literacy as well as ten statements regarding consumer behavior.

Data used primary data obtained through questionnaires, while the source of the data from responses to questionnaires was distributed to 100 high school students and students. The questionnaire consisted of 32 statements divided into five parts consisting of one of the parent's income statement, the statement of conformity 5, 5 statement about the hedonistic lifestyle, 11 statements about financial literacy as well as ten statements regarding consumer behavior. As for how to determine the purpose of the assessment categories are as follows:

1. Determine weight rating consists of strongly agree (5), agree (4), doubt (3), disagree (2), and strongly disagree (1).

2. Calculate the scores of each item statement,

3. The lowest value and the highest value, in this case, the lowest score $=$ number of respondents $\times 1(100 \times 1=100)$. The highest value, the number of respondents multiplied by the weight of the highest value, $100 \times 5=500$.

4. Determine the distance interval from the lowest value to the highest value. Distance interval calculation:

$$
J I=\frac{500-100}{5}+1=81
$$


Sifa Asri Trisnani, Atika Dian Adriyani, Rifky Aulia Wandansari, \& Wikan Isthika

JIEMB | 200

Table 3. Category score

\begin{tabular}{ll}
\hline Category & Score \\
\hline Verylow & $100-180$ \\
Low & $181-261$ \\
moderate & $262-342$ \\
High & $343-423$ \\
Very high & $424-503$ \\
\hline
\end{tabular}

Thus the assessment of each item category statement and assessment can be seen in Table 3. The parents' income variable consists of only one statement. The score values for these variables are 304 . The average for this variable is 304 , who are in the medium category.

In conformity, variables consist of two indicators with five statements. The indicator consists of 1) Normative conformity, 2) Informative conformity. Score values for the variables of conformity are 1693. The average for the variable conformity is 338.6, which is in the medium category.

In the hedonistic lifestyle, variables consist of three indicators with 5 statements. The indicator consists of 1) Activities, 2) Interest, 3) Opinions. Score values for variables hedonistic lifestyle are 1368. The average for the variable hedonistic lifestyle is 273.6, which is in the medium category.

On financial literacy, variables consist of 4 indicators with 11 statements. The indicator consists of 1) Basic knowledge of personal finance, 2) Savings and loans, 3) Insurance, 4) Investment. The value score for the financial literacy variable is 4386 . The average for variable financial literacy is 398.72 , which is in the high category.

In consumer behavior variables consists of 8 indicators with 10 statement. The indicator consists of 1) Discount or gift, 2) Attractive packaging, 3) appearances and prestige, 4) Consideration of the price, 5) Status symbol, 6) Conformity of the model, 7) Confidence, 8) Trying a different brand. The score value for the variable consumer behavior is 3166 . The average for the variable of consumer behavior is 316.6 , which is in the medium category. 
Consumption behavior and the lack of financial literacy....

Table 4. Normality test result with one-sample Kolmogorov-Smirnov test

\begin{tabular}{|c|c|c|c|}
\hline & & & $\begin{array}{c}\text { Residual } \\
\text { unstandardized }\end{array}$ \\
\hline $\mathrm{N}$ & & & 100 \\
\hline \multirow[t]{2}{*}{ Normal Parameters, b } & mean & & OE-7 \\
\hline & Std. deviation & & 3.84523385 \\
\hline \multirow[t]{3}{*}{ Most Extreme Differences } & Absolute & & .093 \\
\hline & positive & & .093 \\
\hline & negative & & -.049 \\
\hline Kolmogorov-Smirnov Z & & & .934 \\
\hline Asymp. Sig. (2-tailed) & & & .348 \\
\hline \multirow[t]{3}{*}{ Monte Carlo Sig. (2-tailed) } & Sig. & & $.332 c$ \\
\hline & $99 \%$ Confidence & Lower Bound & .320 \\
\hline & Interval & Upper Bound & .344 \\
\hline
\end{tabular}

Results of the normality test with the Kolmogorov-Smirnov normality obtained meaning sig $0.33>0.05$, then $\mathrm{HO}$ is accepted (Table 4). This means that the variable is normally distributed consumer behavior.

For multicollinearity test (Table 5), result shows for each independent variable has a value of tolerance $>0.1$ and VIF $<10$. Conformity tolerance value $=0782$ and $\mathrm{VIF}=1,278$, hedonic lifestyle value tolerance and VIF $=0772=$ 1,295 and financial literacy tolerance values and VIF $=0984=1017$. So we can conclude that there is no multicollinearity between independent variables in the regression model.

Based on Table 6, it is obtained by the coefficient of determination (R2) of 0370. This means that the peer conformity, hedonistic lifestyle, and financial literacy contributed $37 \%$ to consumer behavior. The rest $63 \%$ influenced by variables outside (variable not studied).

Based on Table 6, it is obtained by the coefficient of determination (R2) of 0370. This means that the conformity, hedonistic lifestyle, and financial literacy contributed $37 \%$ to consumer behavior. The rest $63 \%$ influenced by variables outside (variable not studied). 
Sifa Asri Trisnani, Atika Dian Adriyani, Rifky Aulia Wandansari, \& Wikan Isthika

Table 5. Multicollinearity test result

JIEMB | 202

\begin{tabular}{lllllllll}
\hline \multirow{2}{*}{ Model } & \multicolumn{2}{l}{$\begin{array}{l}\text { Coefficients } \\
\text { unstandardized }\end{array}$} & $\begin{array}{l}\text { Standardized } \\
\text { Coefficients }\end{array}$ & t & \multicolumn{3}{l}{$\begin{array}{l}\text { Sig. } \\
\text { Collinearity } \\
\text { Statistics }\end{array}$} \\
\cline { 3 - 7 } & & B & Std. Error & beta & & & tolerance & VIF \\
\hline 1 & (Constant) & 19741 & 3,716 & & 5313 & .000 & & \\
& conformity & .040 & .138 & .027 & .294 & .769 & .782 & 1,278 \\
& hedonic & .819 & .127 & .595 & 6453 & .000 & .772 & 1,295 \\
Literacy & .001 & .064 & .001 & .010 & .992 & .984 & 1017 \\
\hline
\end{tabular}

The results of multiple linear regression analysis (Table 7) with the consumer behavior as the dependent variable, and conformity, hedonistic lifestyle and financial literacy as an independent variable, obtained the following regression results.

The conducted simultaneous test aims to show whether all the independent variables included in the model have jointly influence on the dependent variable. F-test with SPSS can be seen in Table 7.

Based on the data in Table 7, it can be seen that the magnitude F 18771 with a significance of 0.000 . With these results, the $\mathrm{H} 1$ is accepted that says their influence conformity variables, hedonistic lifestyle, and financial literacy to the consumer behavior in adolescents high school and university in the Middle Semarang.

Based on Table 8, it can be seen that the results of multiple linear regression analysis of consumer behavior as the dependent variable regression equation as follows:

$$
\mathrm{PK}=19741+0.040 \mathrm{~K}+0.819 \mathrm{G}+0.001 \mathrm{~L}+\mathrm{e}
$$

Table 6. Simultaneous determination coefficient conformity, hedonic lifestyle, and financial literacy on consumer behavior

\begin{tabular}{lllll}
\hline \multicolumn{5}{c}{ Model Summary b } \\
\hline Model & $\mathrm{R}$ & R Square & Adjusted R Square & Std. error of the \\
& & & & Estimate \\
1 & $.608 \mathrm{a}$ & .370 & .350 & 3.90485 \\
\hline
\end{tabular}


Consumption behavior and the lack of financial literacy....

Table 7. Test result $F$ with consumer behavior as the dependent variable

\begin{tabular}{lllllll}
\hline \multicolumn{7}{c}{ ANOVA } \\
\hline Model & & Sum of & df & mean & $F$ & Sig. \\
& & Squares & & Square & & \\
1 & Regression & 858643 & 3 & 286214 & 18771 & $.000 \mathrm{~b}$ \\
& residual & 1463.797 & 96 & 15248 & & \\
& Total & 2322.440 & 99 & & & \\
\hline
\end{tabular}

Information :

PK : Consumptive behavior

$\mathrm{K}$ : Peer conformity

G : Lifestyle Hedonism

L : Financial Literacy

The t-test was conducted to test how high the individual effect of independent variables on the dependent variable. The results of the t-test with SPSS can be seen in Table 8. Based on Table 8, it can be seen that the test results with the SPSS statistical t show consumer behavior as the dependent variable, in conformity obtained by $\mathrm{t}=0.294$ to 0.796 mean $\mathrm{H} 0$ significance of saying no influence variable conformity to consumer behavior.

In the hedonistic lifestyle, variables obtained, $t$ count $=0.6453$ with a significance of 0.000 means that $\mathrm{H} 1$ is accepted. This means a hedonistic lifestyle variables influence consumer behavior. In financial literacy, the $\mathrm{t}$ variable is 0.10 with significance 0 .

The t-test was conducted to test how high the individual effect of independent variables on the dependent variable. The results of the $t$-test with SPSS can be seen in Table 8.

Based on Table 8, it can be seen that the test results with the SPSS statistical t show consumer behavior as the dependent variable, in conformity obtained by $\mathrm{t}=0.294$ to 0.796 mean $\mathrm{H} 0$ significance of saying no influence variable conformity to consumer behavior. 
Sifa Asri Trisnani, Atika Dian Adriyani, Rifky Aulia Wandansari, \& Wikan Isthika

Table 8. Result of multiple linear regression

\begin{tabular}{|c|c|c|c|c|c|c|}
\hline \multicolumn{7}{|c|}{ Coefficients } \\
\hline \multicolumn{2}{|c|}{ Model } & B & Std. Error & $\begin{array}{l}\text { Standardized coefficients } \\
\text { beta }\end{array}$ & $t$ & Sig. \\
\hline 1 & (Constant) & 19741 & 3,716 & & 5313 & .000 \\
\hline & conformity & .040 & .138 & .027 & .294 & .769 \\
\hline & Lifestyle Hedonis & .819 & .127 & .595 & 6453 & .000 \\
\hline & Financial Literacy & .001 & .064 & .001 & .010 & .992 \\
\hline
\end{tabular}

In the hedonistic lifestyle, variables obtained, $t$ count $=0.6453$ with a significance of 0.000 means that $\mathrm{H} 1$ is accepted. This means a hedonistic lifestyle variables influence consumer behavior. In financial literacy, the $t$ variable is 0.10 with significance 0 .

Tests for conformity variable, it can be seen that the result of the $t$ value for the variable conformity of 0294 with significant value 0769 . This suggests that the significant value of the variable is greater than 0.05 conformity stating $\mathrm{H} 0$ and $\mathrm{H} 1$ rejected means the absence of influence of variables adolescent conformity with the consumer behavior of SMA and Universitas in the West Semarang.

Based on the results of the t-test, the result was rejected $\mathrm{H} 0$ and $\mathrm{H} 1$ accepted. In this case, the variable hedonistic lifestyle influence on consumer behavior of students and college students. Heightened lifestyle, the higher the level of consumer behavior demonstrated by the student and the student. This concurs with Hawkins (Kusumaningtyas, 2017), which argues lifestyle affects the needs, desires, and behavior.

With the development of the age in which technology is better as it's been the existence of social media that make the public figure as visual advertising, it certainly makes one also makes its lifestyle change, especially targets which manufacturers are teenagers teens still thinking if the desire is a requirement that must be met. This is in line with Rossanty, et al. (2018) argue one follows whatever his lifestyle (e.g., the person concerned is a public figure) would try to go with the flow and choose the lifestyle they deem convenient, when in 
fact economically that person different from the person who made a role model.

Tests on financial literacy variables can be seen if the value of $t$ at $0: 10$ with a significant value above 0005 is 0995 , it can be stated $\mathrm{HO}$ and $\mathrm{H} 1$ rejected. Based on test results between financial literacy variable towards adolescent consumer behavior in Semarang High School and the University of Central, the conclusion that there is no influence between financial literacy to high school teenagers consumer behavior and Students in Central Semarang. Its high level of financial literacy to someone does not guarantee if someone can financial management is well, and vice versa, low levels of financial literacy in a person can not be implied if a person will behave consumptive.

\section{Conclusion}

According to the research conducted, it can be concluded that the relationship of lifestyle hedonism against juvenile behavior consumer behavior. The higher the lifestyle worn by teens will be followed by its higher consumer behavior, it applies conversely the lower the lifestyle that is used, the lower also consumer behavior of teenagers.

\section{References}

Julian, E., Ananda, N. A., \& Andriani, S. (2018). Analisis Tingkat Literasi Keuangan terhadap Perilaku Konsumtif pada Remaja Sumbawa. jurnaluts.ac.id.

Kusumaningtyas, I. (2017). Pengaruh Literasi Keuangan dan Gaya Hidup terhadap Perilaku Konsumtif Siswa Kelas XI IPS Di SMA Negeri 1 Taman Sidoarjo. Jurnal Pendidikan Ekonomi. Volume 5 Nomor 3.

Nurachma, Y. A., \& Arief, S. (2017). Pengaruh Status Sosial Ekonomi Orang Tua, KelompoK Teman Sebaya dan Financial Literacy terhadap Pwrilaku Konsumtif. Economic Education Analysis Journal.

Perdana, P. I. (2017). Hubungan Antara Konformitas Teman Sebaya dengan Perilaku Konsumtif Membeli Pakaian pada Mahasiswi Angkatan 2016 
Sifa Asri Trisnani, Atika Dian Adriyani, Rifky Aulia Wandansari, \& Wikan Isthika

Fakultas Psikologi Universitas Diponegoro. Jurnal Empati, Volume 6 (Nomor 4).

Ghozali, I.M. (2016). Aplikasi Analisis Multivariete dengan Program IBM SPSS 23. Semarang: Bdan Penerbit Universitas Diponegoro.

Rossanty, Y., Nasution, M. D., \& Ario, F. (2018). Consumer Behavior In Era Milenial. Medan: Lembaga Penelitian dan Penulisan Ilmiah Aqli.

Widyati, I. (2012). Faktor-Faktor yang Mempengaruhi Literasi Finansial Mahasiswa Fakultas Ekonomi dan Bisnis Universitas Brawijaya. Jurnal Akuntansi dan Pendidikan, Volume 1, Nomor 1. 